\title{
DIORITE AND HORNBLENDITE ENCLAVES AT SUMIDOURO, RJ, CENTRAL RIBEIRA BELT
}

\author{
JULIO CEZAR MENDES, MARIA DO CARMO BUSTAMANTE JUNHO \& ANDRE GHIZI
}

\begin{abstract}
Dioritic and hornblenditic enclaves crop out in the southeastern Sumidouro region, Rio de Janeiro State. They are enveloped by tonalitic gneiss of the Rio Negro Complex. In the main occurrence, at Barão de Aquino District, a set of rounded megaenclaves are closely related with the tonalitic gneiss groundmass. Petrographic and geochemical aspects (major, trace and rare earth elements) combined with field relations, support a cumulatic interpretation for the hornblendite. This rock probably evolved by differentiation process from the same parental magma of the diorites. In turn, the tonalitic gneiss shows distinct petrographic and geochemical signature, suggesting a different source.
\end{abstract}

Keywords: Diorites, Enclaves, Rio Negro Complex, Central Ribeira Belt

Resumo ENCLAVES DE DIORITO E HORNBLENDITO EM SUMIDOURO, RJ, CINTURÃO RIBEIRA CENTRAL A sudeste de Sumidouro, região serrana do Estado do Rio de Janeiro, ocorrem enclaves dioríticos e hornblendíticos envolvidos por tonalitognaisse do Complexo Rio Negro. Na principal ocorrência estudada, a do Distrito de Barão de Aquino, megaenclaves arredondados estão concentrados e intimamente relacionados com a matriz tonalito gnáissica. Aspectos petrográficos e geoquímicos (elementos maiores e traços, incluindo terras raras), juntamente com as relações de campo, permitem a interpretação do hornblendito como um cumulado, formado provavelmente a partir do magma que gerou as rochas dioríticas. Por sua vez, o tonalito gnaisse apresentou diferentes assinaturas petrográficas e geoquímicas, o que indica uma origem de fonte diversa.

Palavras-chave: Dioritos, Enclaves, Complexo Rio Negro, Faixa Ribeira central

INTRODUCTION Geological studies focusing tonalitic to dioritic rocks of the Rio Negro Unit (Matos et al. 1980; Barbosa \& Grossi Sad 1985) have been reviewed by Tupinambá(1999), who renamed it as Rio Negro Complex. This author has interpreted the complex as a Brasiliano pre-collisional magmatic arc ranging in age from 660 to $600 \mathrm{Ma}$. This complex is located within the central Ribeira Belt, an important Neoproterozoic (Brasiliano/Pan-African cycle) unit that runs along the southeastern Brazilian coast. The aim of this paper is to present and interpret results from field, petrographical and geochemical studies carried out in a small area of the Rio Negro Complex, near Sumidouro, Rio de Janeiro State.

GEOLOGICAL SETTING The mountain region of the Rio de Janeiro state consists mainly of rocks of the following units: Rio Negro Complex (tonalitic to granodioritic orthogneisses, migmatites), Serra dos Órgãos batholith (granodioritic orthogneisses), Leucogranitic gneisses and minor amounts of metasedimentary rocks of the Paraíba do Sul Group. Several brasiliano age igneous rocks, ranging from granite to granodiorite, and rarely gabbros, intrude those units.

The Rio Negro Complex was initially described as an association of granitic orthogneisses and heterogeneous migmatites (Matos et al. 1980; Barbosa \& Grossi Sad 1985). Machado \& Demange (1994) considered the Rio Negro orthogneisses as a Palaeoproterozoic basement. Recent works have pointed out the arc related nature of the Rio Negro Complex (Tupinambá 1999, Heilbron et al. 2000). Tupinambá (1999) interpreted such magmatism as a pre-collisional event which generated Cordilleran-type, calc- alkalic granodioritic to tonalitic and dioritic rocks. A U-Pb zircon age of $634 \pm 10 \mathrm{Ma}$ was obtained for the typıcal tonalitic gneiss of this unit (Tupinambá 1999).

Banded to homophonous leucogranite gneisses crosscut the Rio Negro rocks, yielded a $\mathrm{Pb} / \mathrm{Pb}$ age of ca. $600 \mathrm{Ma}$ and were defined as an individual unit of pre to syn-collisional, S-type granites, by Tupinambá (1999).

The Serra dos Órgãos batholith comprises a garnet-hornblendebiotite granitic to granodioritic gneiss surrounded by the Rio Negro

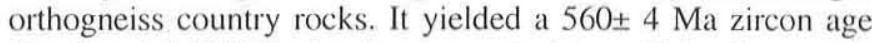
(Tupinambá 1999), related to a syn- to late-collisional orogenic event. It has a conspicuous foliation given by mafic aggregates and subordinated diktionic structures.

The granitic to granodioritic plutons constitute a large late- to post-collisional granitic province that extends from southwest to northeast Rio de Janeiro State. Geochronogical whole rock Rb-Sr and $\mathrm{U}-\mathrm{Pb}$ in zircon data indicate ages ranging from $540 \mathrm{Ma}$ to 480 $\mathrm{Ma}$ (Trouw et al. 2000). Subordinate diorites in close association with the granitoids have also been reported (Junho 1993, Junho et al. 1993, Mendes et al. 2002).

The gabbroic bodies are lenticular in shape, isotropic or foliated and calc-alkalic to tholeiitic. They range from hornblende gabbro, pyroxene-hornblende gabbro to hornblendites and may have been emplaced during or late the $580 \mathrm{Ma}$, high-grade regional metamorphism (Tupinambá 1999; Junho et al. 1999).

THE RIO NEGRO MAGMATIC ARC AT SUMIDOURO According to Tupinambá (1999), the Sumidouro area consists

Depto. de Geologia - IGEO - UFRJ. Cidade Universitária, CEP 21949-900, Ilha do Fundão, Rio de Janeiro-RJ. E-mails: julio@geologia.ufrj.br, mjunho@gcologia.ufrj.br, ghizi@acd.ufrj.br 
mainly of (hornblende) tonalitic to granodioritic gneiss and leucogranite gneiss. Dioritic rocks occur ca. $25 \mathrm{Km}$ southeast of Sumidouro. In the present study a small unmapped occurrence of basic to intermediate rocks (diorites/meladiorite and hornblendite), located at Barão de Aquino District, near Sumidouro (Fig. 1), is described. The occurrence is an irregularly shape megaenclave, cropping out in an area of ca. $1 \mathrm{~km}^{2}$ and completely surrounded by the tonalitic to granodioritic gneiss. Such gneiss is in contact with the metasedimentary rocks at the north and with the younger leucogranite gneiss at the south.

Metasedimentary rocks The banded metasedimentary rocks are characterized by centimetric to decimetric interbedded quartzites, calc-silicate rocks and muscovite-biotite gneiss. They are folded rocks with NNW axial plane. The metatexitic gneisses are (garnet)(muscovite)-(hornblende)- biotite gneisses showing stromatic migmatitic structure and subordinate nebulitic, ophthalmitic and schlieren structures. Under the microscope the mesosome contains plagioclase $\left(A n_{40}\right)$, biotite, hornblende, quartz, epidote, sphene, calcite and sparse garnet and muscovite. Locally calc-silicate rocks form centimetric lenticular enclaves.

Tonalitic Gneiss This orthoderived lithotype crops out extensively throughout the area. It contains the diorites/meladiorite and hornblendite megaenclaves and is cut by the leucogranite gneiss (Fig. 1). Petrographic evidence revealed variations from tonalitic to quartzdioritic composition. It is leucocratic to mesocratic and has inequigranular, locally porphyritic texture given by larger plagioclase crystals. It consists essentially of plagioclase $\left(\mathrm{An}_{26-33}\right.$, and $\mathrm{An}_{42}$ for the phenocrysts), quartz, biotite and hornblende. Syneusis texture is found in the plagioclase phenocrysts. Opaque minerals, sphene, rutile, zircon and apatite are the accesory minerals. Its discontinuous foliation is mainly marked by interconnected felsic and mafic aggregates. Centimetric to metric dioritic and hornblenditic enclaves commonly occur, in some cases as enclave swarms. The Barão de Aquino District megaenclave occurrence is probably genetic related to such smaller enclaves.

Barão de Aquino Diorites and Hornblendite These lithotypes are subordinate and enclosed by the tonalitic gneiss. They appear as a heterogeneous set of enclaves intermingled with the tonalitic gneiss (Figs. 2, 3, 4, 5). The enclaves have variable sizes and are rounded to angular (Fig. 4), showing both gradational and sharp contacts. Locally they have elongated shapes displayed in a banded structure with the tonalitic gneiss. It is noteworthy the presence of double enclaves (Didier 1973 - Fig. 5). Meladiorite and microdiorite occur associated with the diorite. The meladiorite grades into hornblendite by the progressive decrease in plagioclase, as described by Hatch et al. (1975). Locally, in particular at the contact zones, the tonalitic gneiss appears as rounded enclaves in the diorites (Fig. 3).

The diorites have a wide grain size range, from very fine to medium. They are mesocratic, hypidiomorphic granular, locally showing poligonal plagioclase. Occasionally they show a foliation marked by oriented mafic aggregates. Elongated plagioclase crystals $\left(\mathrm{An}_{30-40}\right)$ up to $5 \mathrm{~mm}$ is the most abundant phase. Hornblende makes up ca. $30 \%$ in vol. mainly as aggregates with biotite, apatite, zircon, sphene and opaque minerals. Quartz and biotite are accessory phases. The mafic aggregates locally characterize a glomeroporphyritic texture, in which biotite may reach up to $10 \%$ in vol. In such case, the rock develops a spotted aspect. Milimetric size felsic lenses may occur inside the diorites/ meladiorite.

The color index of the hornblendite ranges from $65 \%$ to $95 \%$. The rock is composed of fine to medium-grained hornblende (up to $50 \%$ in vol.), biotite, plagioclase and opaque minerals, with accessory sphene, apatite, quartz and zircon. Rutile occurs when ilmenite and sphene are nearby absent. Interconnected aggregates of hypidiomorphic hornblende are surrounded by plagioclase and subordinate quartz, resulting a cumulus texture. Together with the dominance of a mafic phase, this texture strengthens the cumulatic origin for this lithotype. Biotite replaces hornblende and both may be slightly oriented.

Leucogranite Gneiss This orthogneiss occurs extensively in the south of the study area, and as dikes and veins cutting all other rock types. It shows sharp and concordant contacts (Fig. 1). This is a foliated, hololeucocratic, xenomorphic equigranular and medium-grained monzogranite, composed of microcline, quartz, plagioclase $\left(\mathrm{An}_{15-18}\right)$, biotite and accessory apatite, zircon and sphene. Oriented biotite flakes mark the foliation of the rock. Angular xenolithic enclaves of diorite, hornblendite and mostly tonalitic gneiss are common. Locally, the abundance of xenoliths may result in a breccia structure. A net veined structure may be observed where abundant leucogranite dikes cut the tonalitic gneiss. Metric lenses of magnetite-bearing pegmatite are found.

GEOCHEMISTRY Five diorite, two hornblendite and two tonalitic gneiss samples were selected for whole rock major and trace element analysis (Table 1). Two additional tonalitic gneiss and one diorite were extracted from Tupinambá (1999). Rare-earth element analysis was carried out on six samples (Table 2).

Analytical methods Analyses of major and trace elements were carried out at the Dept. of Geology, Federal University of Rio de Janeiro, using a Philips PW2400 Rh tube X ray Fluorescence spectrometer. Loss-on-ignition was measured by weighting the rock powder before and after ignition at $950^{\circ} \mathrm{C}$ for $30 \mathrm{~min}$. Major elements were detected on 1,2 g of rock powder fused with lithium tetraborate. Trace elements were determined on $7 \mathrm{~g}$ of rock powder pressed with $1 \mathrm{~g}$ of wax agglutinate. Flow detector, PET/Ge analyzer crystals and $40 \mathrm{kV}-70 \mathrm{~mA}$ power tube were the determination conditions for light elements. Heavy elements were detected with sealed detector, LIF200/LIF220 analyzer crystals and $50 \mathrm{kV}-50 \mathrm{~mA}$ power tube. Based on standards analysis relative analytical uncertainties are estimated as follow: $\mathrm{Si}, \mathrm{Al}(<1 \%), \mathrm{Fe}, \mathrm{Mg}, \mathrm{Ca}(1-$ $2 \%)$, Ti, Na, K (3-5\%), P and other trace alements ( $\leq 6 \%)$. The calibration curves were obtained from analysis of the following international standards: NIM-P, 521-84n, GBW07112, GIT-IWG, ANRT, BE-N GIT, PM-S GIT, CRPG BR, AN-G GIT, GBW07104, GBW07110, GBW07111, AC-E, GS-N, MA-N, CRPGGH.

Rare-earth element analysis were performed at Lakefield/Geosol Laboratory, Belo Horizonte, Minas Gerais State, using an ICP-AS spectrometer (Dutra et al. 1986).

The $\mathrm{SiO}$, content ranges from $46 \mathrm{wt} \%$ to $63 \mathrm{wt} \%$. The hornblendite has the lowest $\mathrm{Al}_{2} \mathrm{O}_{3}$ and the highest $\mathrm{MgO}$ concentrations. On the other hand, the tonalitic gneiss shows the highest $\mathrm{SiO}_{2}$ and the lowest $\mathrm{CaO}$ contents. The diorites and hornblendite have significant $\mathrm{CaO}$ and $\mathrm{Fe}_{2} \mathrm{O}_{3}$ amounts when compared to the tonalitic gneiss. Among the trace elements, $\mathrm{Ba}$ and $\mathrm{Sr}$ show the highest concentrations. High $\mathrm{Ba}$ and $\mathrm{Sr}$ values have already been reported for the Brasiliano/Pan-African Rio de 


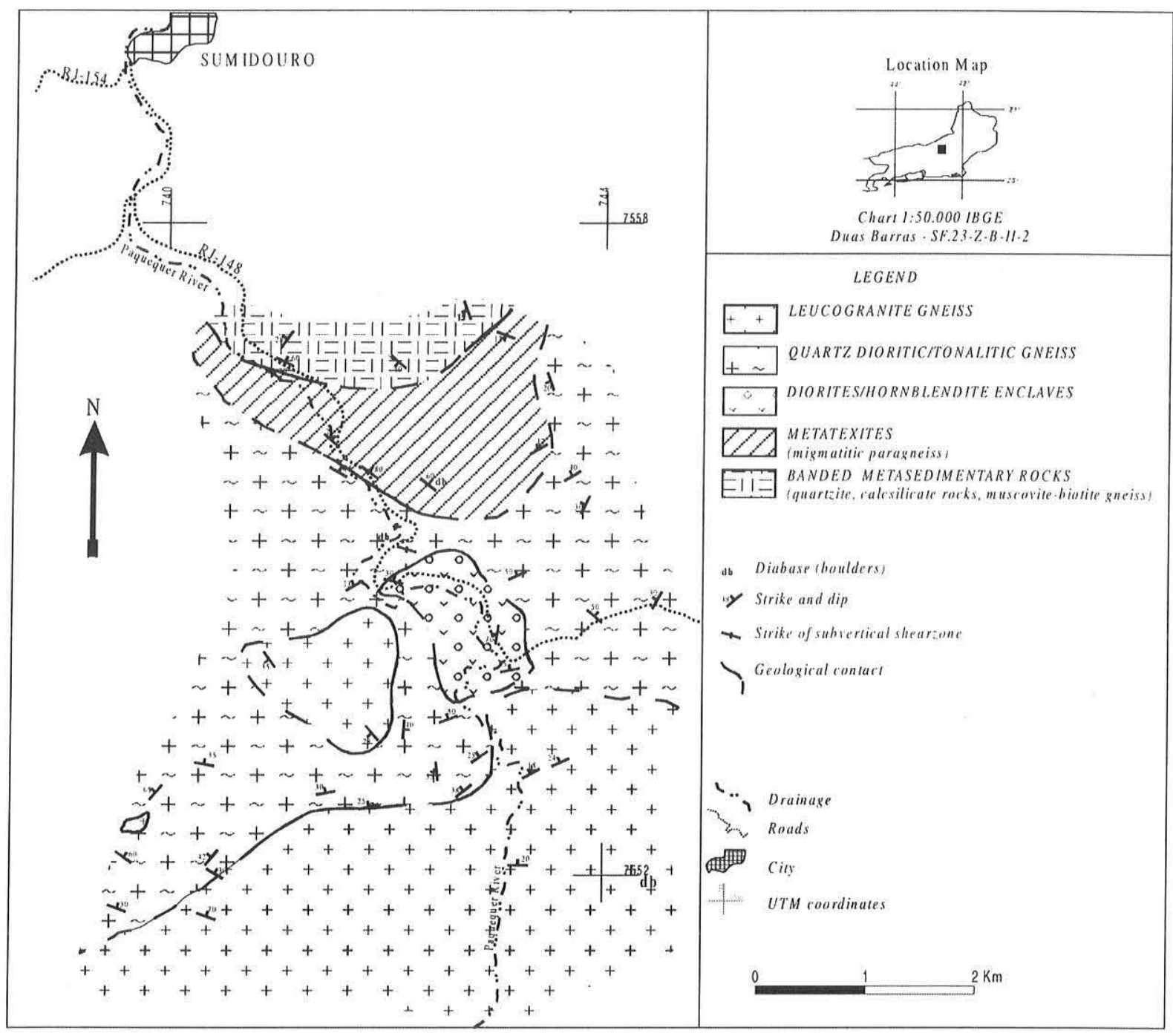

Figure I-Geological map of the southeast Sumidouro area.

Janeiro-Espírito Santo calc-alkaline province (Junho 1993, Ludka et al. 1998, Medeiros et al. 2000, Mendes et al. 1997). It is noteworthy the high $\mathrm{Ni}$ and mainly $\mathrm{Cr}$ contents of the hornblendite.

The diorites and tonalitic gneiss have a clear non-tholeiitic, probably calc-alkaline and metaluminous character, as observed in figures 6 and 7. The hornblendite, interpreted here as cumulate, show a scattered behaviour in the Harker diagrams (Fig. 8). Otherwise, it shows contrasting $\mathrm{K}_{2} \mathrm{O}, \mathrm{TiO}_{2}, \mathrm{Ba}$ and $\mathrm{Sr}$ values, probably related to different modal proportions of biotite, plagioclase and, perhaps, opaque mineral.

The tonalitic gneiss outlines trends for almost all the elements (Fig. 8). The diorites tend to be scattered or show different trends. $\mathrm{SiO}_{2}$ contents around $55 \mathrm{wt} \%$ mark a boundary between these two geochemically compositional groups. The NCK diagram (Fig. 9) emphasizes these differences, and may point to a non-cogenetic relation between the lithotypes.

The scattering of the data for the diorites could be due to the varying proportions of biotite, plagioclase and hornblende, which may reach up to $20 \%$ in each one.

Figure $10(a, b, c)$ shows the MORB-normalized trace-element patterns for each rock group. The diorites and hornblendite resemble each other, except by the conspicuous $\mathrm{Zr}$ and $\mathrm{Sr}$ negative anomalies of the later. The tonalitic gneiss pattern stands out against the other lithotypes by the higher $\mathrm{K}, \mathrm{Ba}$ and $\mathrm{Rb}$ and lower $\mathrm{Sr}$ and $\mathrm{Ti}$ concentrations.

The rare-earth element behaviour (Fig. 11) emphasizes the similarity between hornblendite and diorite. They show low to medium total REE contents and slight rare-earth fractionation (La/ $\mathrm{Yb}$ ratios ranging from 14.23 to 56.98 - table 2) with a slight Eu anomaly. In turn, the tonalitic gneiss pattern is more fractionated, revealing lower HREE contents.

DISCUSSION AND CONCLUSIONS The studied lithotypes, tonalitic gneiss, diorites and hornblendite, revealed a close field association. Nevertheless, their petrographic, textural and geochemical aspects provide evidences to separate them according to their affinities and differences. In this way, the diorites and hornblendite are probably cogenetic, as indicated by their gradational contacts, similar rare earth element patterns, mineralogy, texture, as well as the presence of hornblendite enclaves in the 


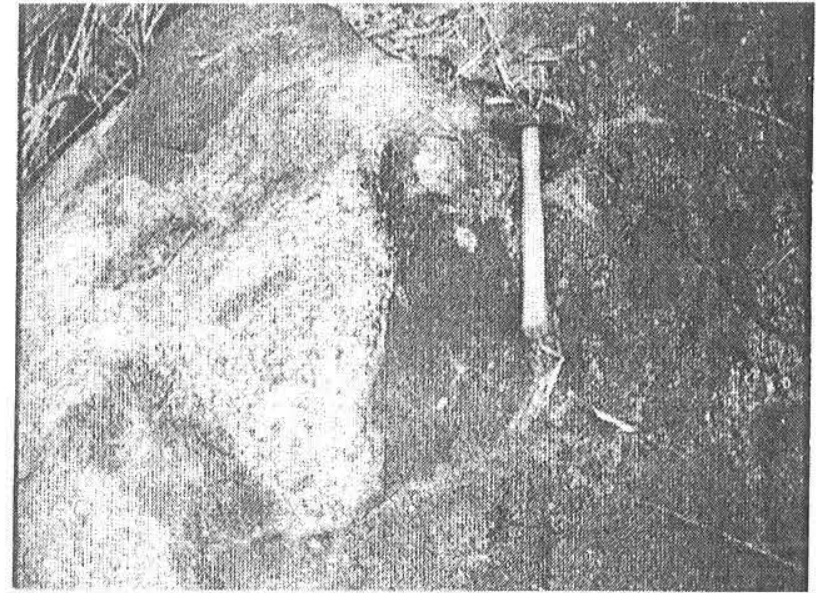

Figure 2 - Contact relations between the tonalitic gneiss and the diorites/hornblendite enclaves. Note also the hornblenditic enclaves in the dioritic groundmass.

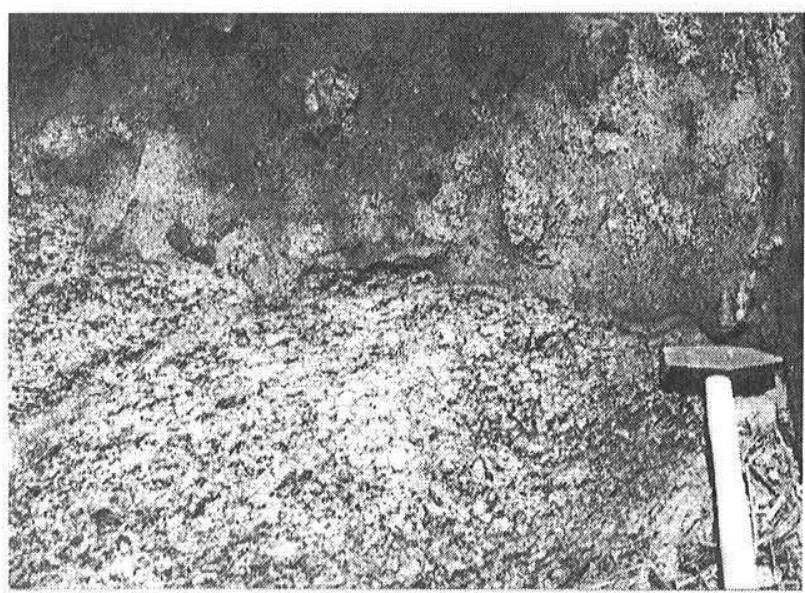

Figure 3 - Irregular contact between the tonalitic gneiss and the dioritic enclaves. Note the tonalitic gneiss enclaves in the dioritic groundmass.

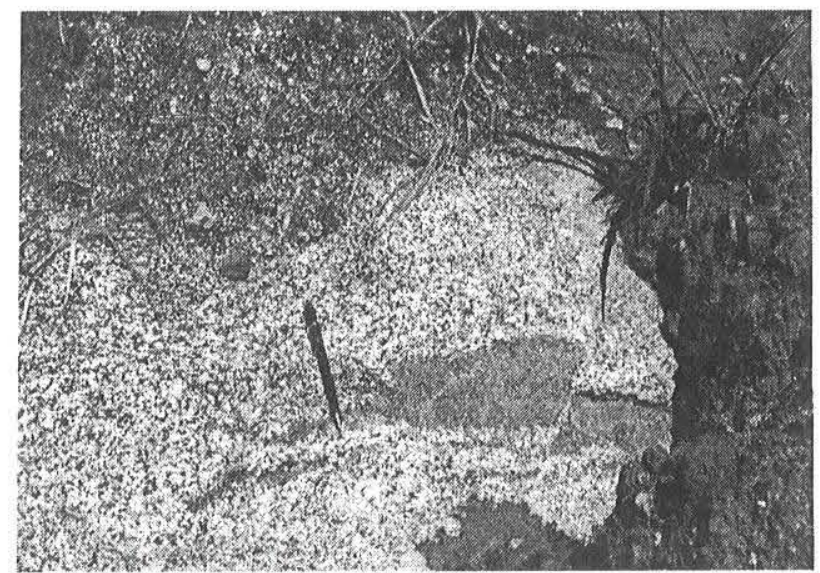

Figure 4 - Disrupted dioritic enclave in the tonalitic gneiss.

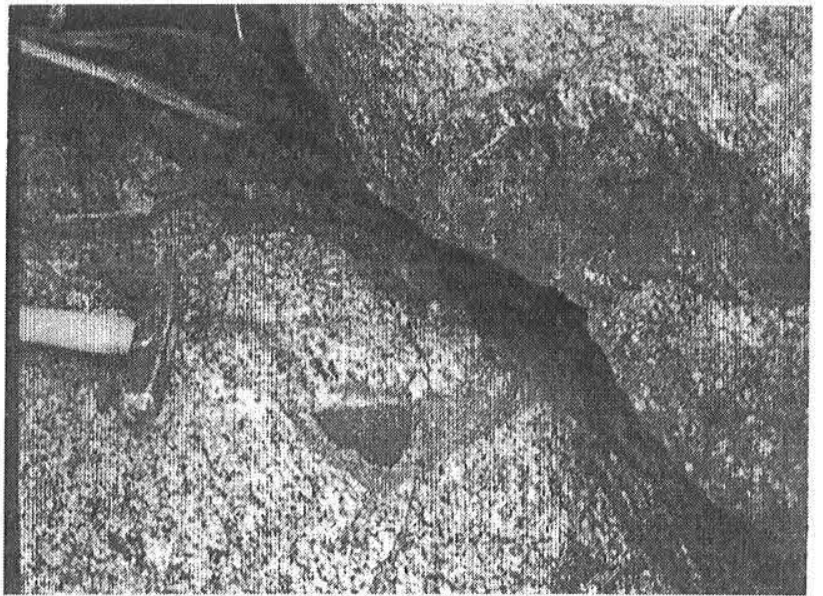

Figure 5 - Double hornblenditic-dioritic enclave surrounded by the tonalitic gneiss.

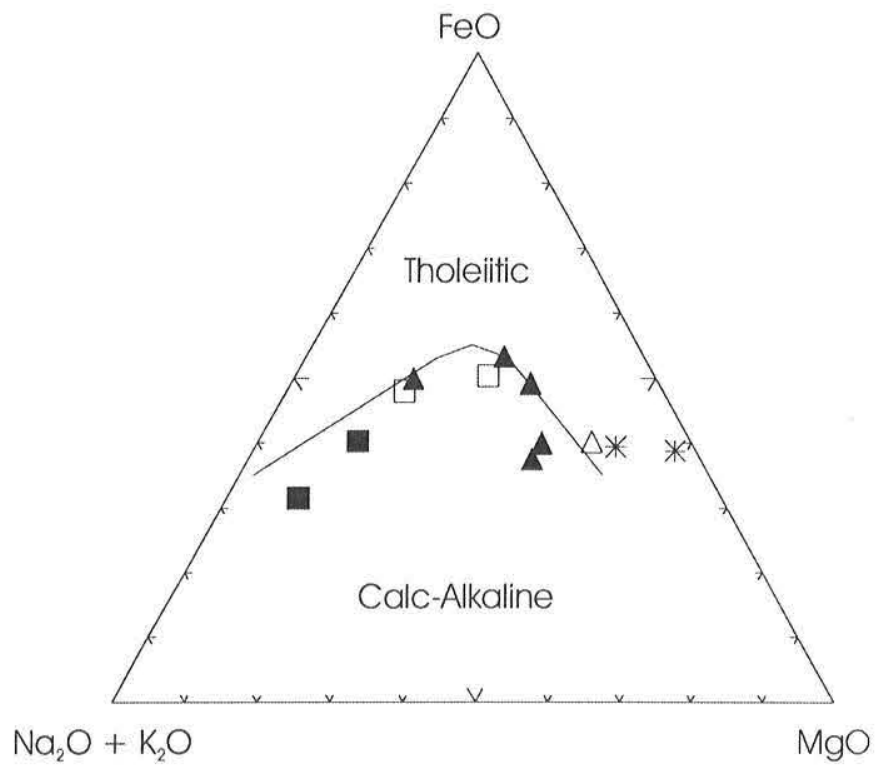

Figure 6 - AFM diagram for the Sumidouro rocks. Symbols: asterisk - hornblendite; solid triangle - diorites (open triangle diorite from Tupinambá 1999); solid square - tonalitic gneiss, open square - tonalitic gneiss from Tupinambá (1999). Calcalkaline boundary line from Irvine \& Baragar (1971).

diorites and vice versa.

Although the tonalitic gneiss encloses the hornblendite/diorites enclaves in different scales, its mineralogical composition and geochemical behaviour point to another source. In spite of the restrict sampling, this lithotype shows a considerable chemical variation and well defined magmatic trends.

The local presence of small rounded tonalitic gneiss enclaves in the diorites suggests a contemporary intrusion for the prior magmas. Such possibility is coherent with the magmatic-arc nature of these rocks, as proposed by Tupinambá (1999).

Although the Sumidouro diorites/hornblendite association contains quartz, it does not have modal $\mathrm{K}$-feldspar. The occurrence 
Table I - Major (wt\%) and trace (ppm) element analysis for the Sumidouro rocks.

\begin{tabular}{|c|c|c|c|c|c|c|c|c|c|}
\hline & $\begin{array}{l}\text { Diorite } \\
\text { 2B14-4 }\end{array}$ & $\begin{array}{l}\text { Diorite } \\
2 \mathrm{~B}-23\end{array}$ & $\begin{array}{l}\text { Diorite } \\
2 \mathrm{~B}-22\end{array}$ & $\begin{array}{l}\text { Diorite } \\
\text { 2B14-1 }\end{array}$ & $\begin{array}{l}\text { Diorite } \\
\text { 2B14-5 }\end{array}$ & $\begin{array}{c}\text { Hornblendite } \\
\text { 2B14-3 }\end{array}$ & $\begin{array}{c}\text { Hornblendite } \\
2 \mathrm{~B} 14-3 p\end{array}$ & $\begin{array}{c}\text { Tonalitic gn } \\
2 B-19\end{array}$ & $\begin{array}{c}\text { Tonalitic gn } \\
\text { 2B-33 }\end{array}$ \\
\hline $\mathrm{SiO}_{2}$ & 45.96 & 47.30 & 49.31 & 51.89 & 52.10 & 53.37 & 49.26 & 61.96 & 63.04 \\
\hline $\mathrm{Al}_{2} \mathrm{O}_{3}$ & 17.78 & 18.01 & 15.80 & 18.18 & 21.79 & 5.61 & 10.29 & 16.93 & 17.72 \\
\hline $\mathrm{Fe}_{2} \mathrm{O}_{3} \mathrm{t}$ & 11.47 & 12.30 & 9.83 & 7.63 & 8.50 & 12.09 & 11.40 & 6.02 & 4.54 \\
\hline $\mathrm{MnO}$ & 0.13 & 0.20 & 0.14 & 0.13 & 0.07 & 0.22 & 0.15 & 0.11 & 0.08 \\
\hline $\mathrm{MgO}$ & 6.93 & 5.67 & 8.66 & 7.15 & 2.53 & 16.40 & 12.96 & 1.84 & 1.29 \\
\hline $\mathrm{CaO}$ & 10.30 & 10.26 & 8.85 & 9.58 & 8.09 & 10.79 & 10.02 & 4.86 & 3.63 \\
\hline $\mathrm{Na}_{2} \mathrm{O}$ & 3.22 & 2.92 & 2.51 & 3.83 & 4.13 & 0.65 & 1.63 & 4.31 & 4.61 \\
\hline $\mathrm{K}_{2} \mathrm{O}$ & 0.54 & 1.14 & 2.13 & 0.47 & 1.05 & 0.17 & 1.21 & 1.88 & 3.00 \\
\hline $\mathrm{TiO}_{2}$ & 1.95 & 1.29 & 1.53 & 0.72 & 1.21 & 0.68 & 1.56 & 0.80 & 0.63 \\
\hline $\mathrm{P}_{2} \mathrm{O}_{5}$ & 0.49 & 0.22 & 0.54 & 0.13 & 0.33 & 0.03 & 0.37 & 0.25 & 0.32 \\
\hline LOI & 0.76 & 1.20 & 1.14 & 0.70 & 0.71 & 1.23 & 1.62 & 0.78 & 0.67 \\
\hline Total & 99.53 & 100.50 & 100.43 & 100.41 & 100.50 & 101.24 & 100.47 & 99.74 & 99.53 \\
\hline $\mathrm{Cr}$ & 142 & 30 & 332 & 83 & 0 & 1009 & 530 & 0 & 0 \\
\hline $\mathrm{Ni}$ & 69 & 31 & 124 & 68 & 33 & 223 & 211 & 32 & 31 \\
\hline Co & 36 & 24 & 35 & 29 & 15 & 61 & 47 & 29 & 20 \\
\hline V & 220 & 167 & 189 & 119 & 154 & 116 & 194 & 126 & 118 \\
\hline $\mathrm{Zn}$ & 78 & 76 & 89 & 76 & 72 & 92 & 82 & 78 & 76 \\
\hline $\mathrm{Rb}$ & 43 & 53 & 71 & 43 & 56 & 40 & 50 & 78 & 89 \\
\hline $\mathrm{Ba}$ & 107 & 123 & 791 & 140 & 398 & 19 & 193 & 808 & 1034 \\
\hline $\mathrm{Sr}$ & 819 & 282 & 660 & 951 & 1310 & 73 & 351 & 343 & 357 \\
\hline $\mathrm{Nb}$ & 11 & 9 & 12 & 9 & 8 & 8 & 10 & 13 & 12 \\
\hline $\mathrm{Zr}$ & 152 & 52 & 219 & 189 & 265 & 7 & 68 & 179 & 207 \\
\hline $\mathrm{Y}$ & 23 & 17 & 19 & 15 & 8 & 12 & 17 & 31 & 26 \\
\hline $\mathrm{Ga}$ & 10 & 9 & 9 & 10 & 10 & 7 & 8 & 10 & 10 \\
\hline
\end{tabular}

gn=gneiss

Table 2 - Rare-earth element (ppm) analysis for the Sumidouro rocks.

\begin{tabular}{|l|cccccc|}
\hline & $\begin{array}{c}\text { Diorite } \\
2 \mathrm{~B}-23\end{array}$ & $\begin{array}{c}\text { Diorite } \\
2 \mathrm{~B}-14-4\end{array}$ & $\begin{array}{c}\text { Diorite } \\
2 \mathrm{~B}-14-1\end{array}$ & $\begin{array}{c}\text { Hornblendite } \\
2 \mathrm{~B}-14-3 \mathrm{p}\end{array}$ & $\begin{array}{c}\text { Hornblendite } \\
2 \mathrm{~B}-14-3\end{array}$ & $\begin{array}{c}\text { Tonalitic gn } \\
2 \mathrm{~B}-33\end{array}$ \\
\hline $\mathrm{La}$ & 10.67 & 33.00 & 15.65 & 25.64 & 27.91 & 20.37 \\
$\mathrm{Ce}$ & 25.84 & 60.48 & 37.87 & 36.50 & 63.49 & 36.76 \\
$\mathrm{Nd}$ & 13.95 & 32.91 & 19.01 & 21.14 & 26.43 & 18.96 \\
$\mathrm{Sm}$ & 3.51 & 9.81 & 4.32 & 4.21 & 6.51 & 3.28 \\
$\mathrm{Eu}$ & 1.09 & 2.17 & 1.15 & 0.97 & 1.67 & 0.87 \\
$\mathrm{Gd}$ & 3.06 & 8.23 & 3.07 & 2.84 & 4.32 & 2.43 \\
$\mathrm{Dy}$ & 2.17 & 5.58 & 1.78 & 1.92 & 3.04 & 1.30 \\
$\mathrm{Ho}$ & 0.43 & 1.04 & 0.34 & 0.34 & 0.55 & 0.22 \\
$\mathrm{Er}$ & 1.05 & 2.29 & 0.75 & 0.74 & 1.27 & 0.43 \\
$\mathrm{Yb}$ & 0.75 & 1.30 & 0.43 & 0.45 & 0.66 & 0.39 \\
$\mathrm{Lu}$ & 0.12 & 0.19 & 0.07 & 0.07 & 0.10 & 0.05 \\
$\mathrm{Total}$ & 62.64 & 156.50 & 84.44 & 94.82 & 135.95 & 85.06 \\
$\mathrm{La} / \mathrm{Yb}$ & 14.23 & 25.38 & 36.39 & 56.98 & 42.29 & 52.23 \\
$\mathrm{SiO}_{2}$ (wt\%) & 47.30 & 45.96 & 51.89 & 49.26 & 53.37 & 63.04 \\
\hline
\end{tabular}




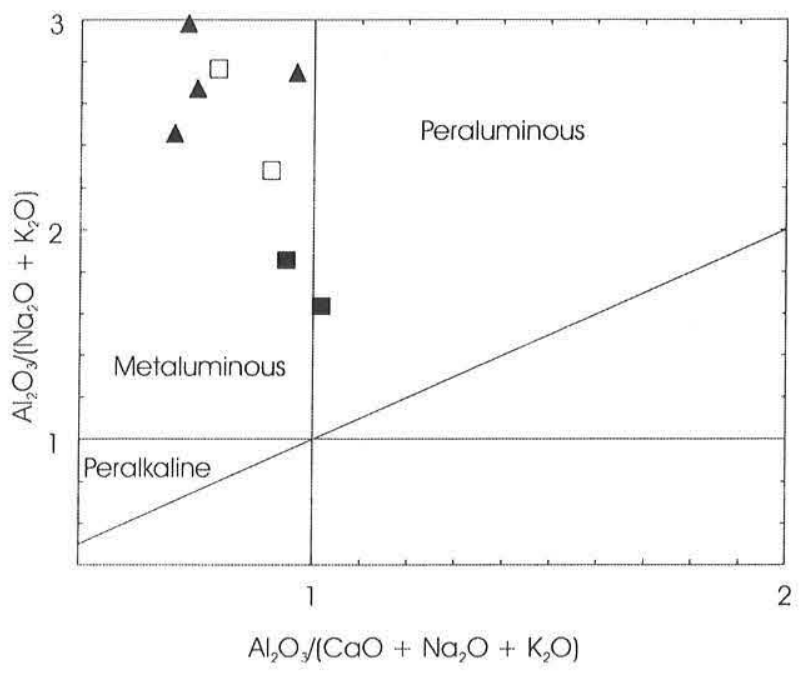

Figure 7 - Shand's diagram for the Sumidouro rocks. Symbols as in figure 6.

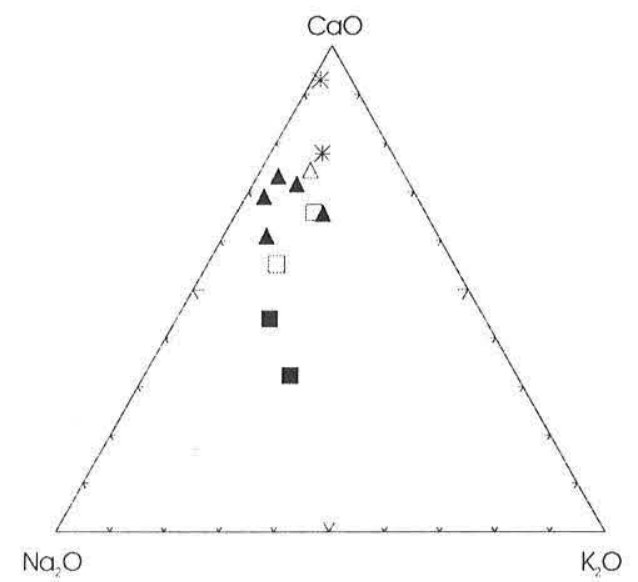

Figure 9 - NCK diagram for the Sumidouro rocks. Symbols as in figure 6.

of quartz in a hornblendite has been mentioned by Deer (1950) and Hatch et al. (1975) in Scotland appinites. According to these authors, the appinite suite includes a wide range of rock types of different compositions, mainly of syenitic or dioritic character, always presenting a great amount of hornblende. On the other hand, Burns (1985) and Snoke et al. (1981) described a hornblende + plagioclase + quartz association in arc-related hornblende gabbros and diorites from south-central Alaska and Klamath Mountains, California, respectively.

The hornblende-rich rocks from Klamath Mountains, California, have been interpreted as products of hydrous magma similar to high-Al basalt and basaltic andesite. The Sumidouro hornblendite is interpreted here as a cumulate, probably from the dioritic magma, as reported by Hatch et al. (1975) and Mercy (1965) for the Scottish diorite-appinite association. The high $\mathrm{Cr}$ contents of the hornblendite probably indicate previous pyroxene- cumulate.

Acknowledgements To FAPERJ (grant E-26/171.423/98) for the financial support of the research and to three anonymous reviewers of the RBG for improving the manuscript.
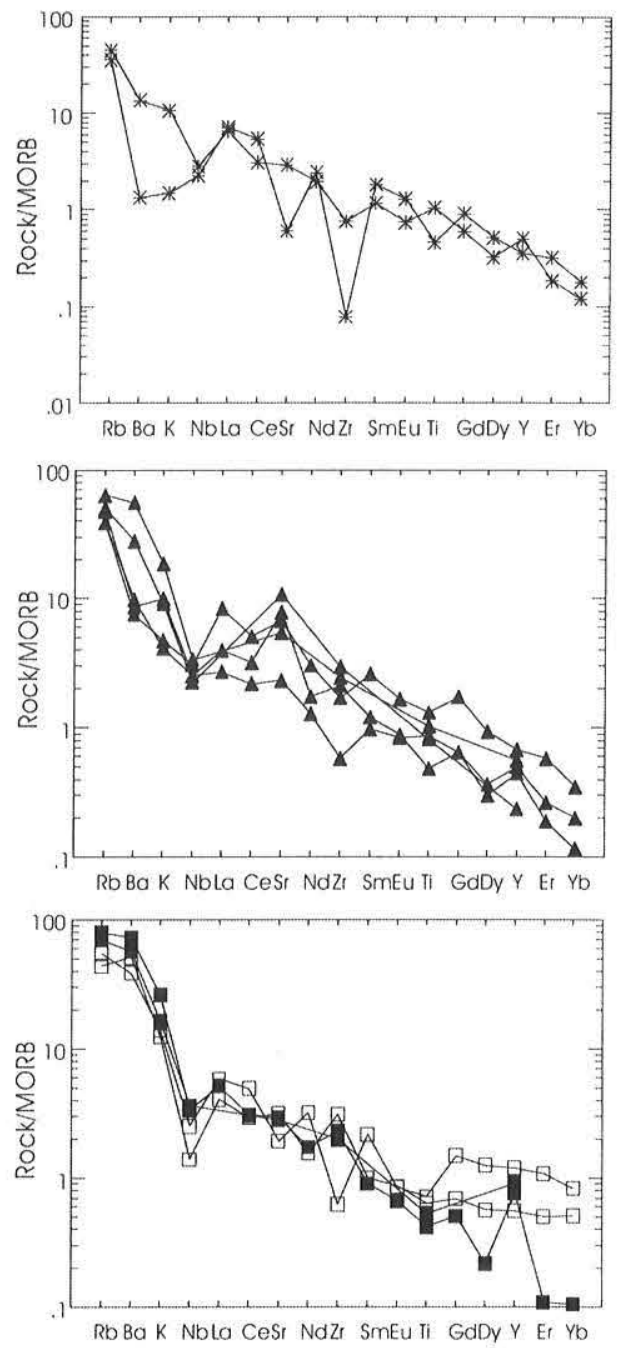

Figure 10 - MORB-normalized multielement diagrams for the Sumidouro rocks. a) Hornblendite; b) Diorites; c) Tonalitic gneiss. Symbols as in figure 6. Normalization values from Sun \& McDonough (1989).

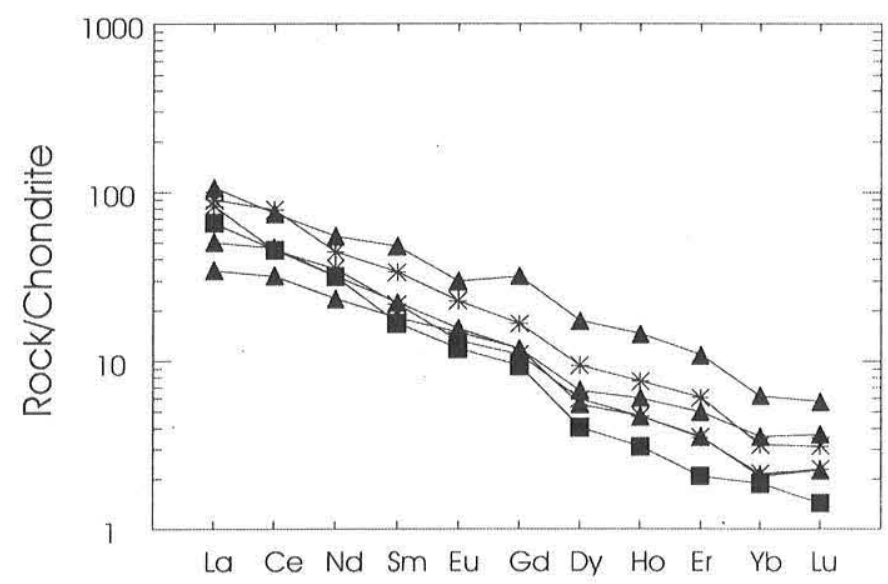

Figure 11 - Chondrite-normalized REE diagram for the Sumidouro rocks. Symbols as in figure 6. Normalization values from Boynton (1984). 

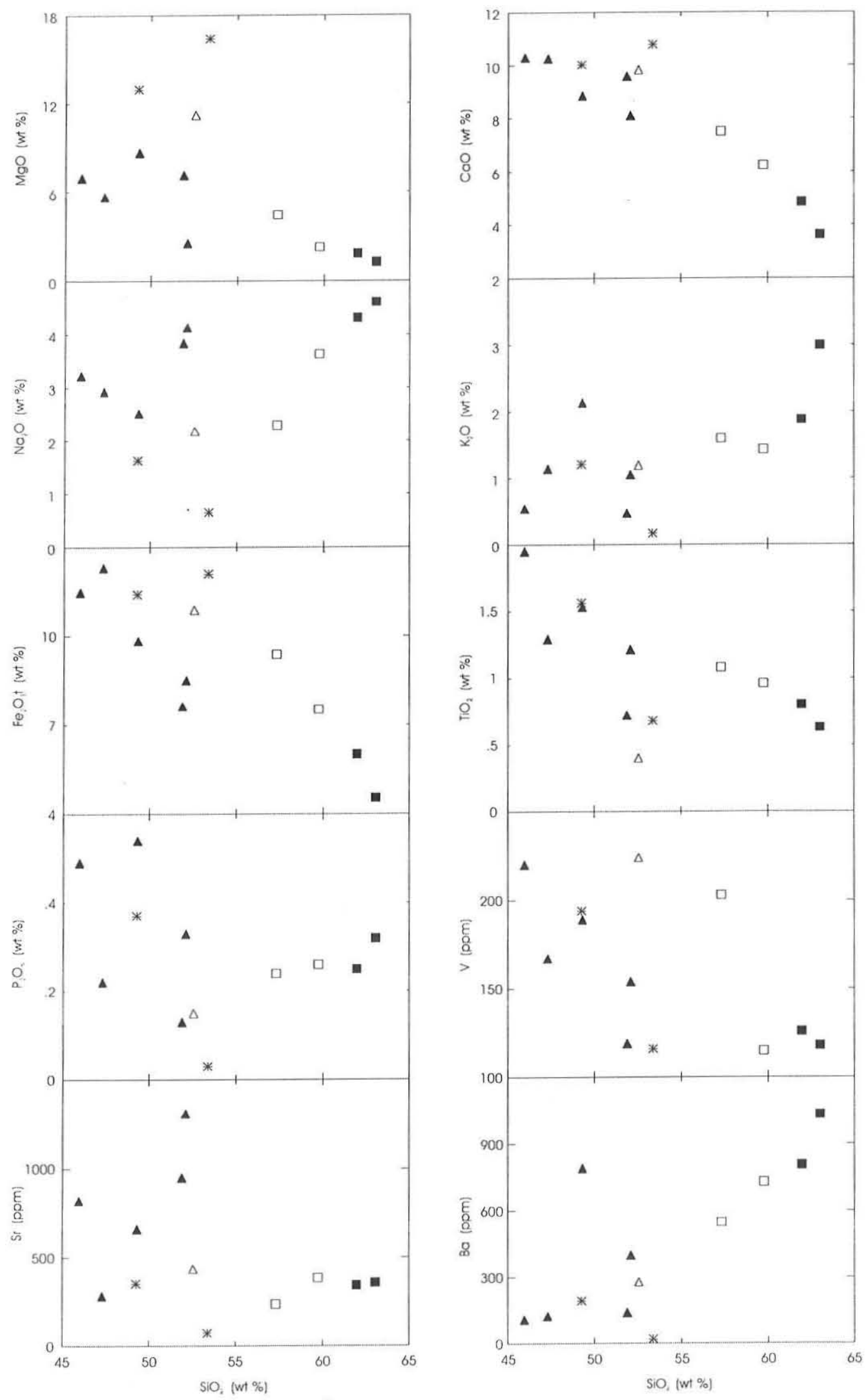

Figure 8 - Harker diagrams of the Sumidouro rocks. Symbols as in figure 6. 


\section{References}

Barbosa A.L.M. \& Grossi Sad J.H. 1985. Batólito granítico da Serra dos Órgãos, Estado do Rio de Janeiro, Brasil. Contribuições à Geologia e a Petrologia, Núcleo de Minas Gerais-SBGM 1985, pp. 49-61.

Boynton W.V. 1984. Cosmochemistry of the rare earth element: meteorite studies. In: P. Henderson (ed.) Rare Earth Element Geochemistry. Amsterdan, Elsevier, pp. 63-114.

Burns L.E.. 1985. The Border Ranges ultramafic and mafic complex. south-central Alaska: cumulate fractionates of island-arc volcanics. Can. J. Earth Sci., 22: 1020-1038.

Deer W.A. 1950. The diorites and associated rocks of the Glen Tilt Complex, Pertshire. II. Diorites and Appinites. Geol. Mag., 37: 181-195.

Didier J. 1973. Granites and their enclaves: the bearing of enclaves on the origin of granites. Elsevier Publ., 393 pp.

Dutra C.V., Grossi Sad J.H., Pedrosa Soares A.C. 1986. Terras raras em litogeoquímica - I. exemplo de esquemas de distribuição em rochas graníticas. Rev. Bras. Geoc., 16:224-228.

Hatch F.H., Wells A.K., Wells M.K. 1975. Petrology of the igneous rocks. 15th Edition, George Allen \& Unwin Ltd., London, 551 pp.

Heilbron M.P., Valeriano C., Almeida J.C., Tupinambá M., Valadares C.S., Duarte B.P., Eirado L.G., Junho M.C., Schmitt R.S. 2000. Tectonic map of the Central Ribeira Orogenic Belt. In: SBG, Geological International Congress, 31, Rio de Janeiro. Abstracts.

Irvine T.N. \& Baragar W.R. 1971. A guide to chemical classification of the common volcanic rocks. Can. J. Earth Sci., 8:523-548.

Junho M.C.B. 1993. Granitos brasilianos do Estado do Rio de Janeiro Considerações geoquímicas. An. Acad. Bras. Ci., 65:161-179

Junho M.C.B., Mendes J. C., Ludka I.P. 1999. O gabro de Marcos da Costa, município de Miguel Pereira (RJ): magmatismo toleítico a cálcio-alcalino na Faixa Ribeira. Rev. Bras. Geoc., 29:595-602.

Ludka I. P., Wiedemann C.M., Töpfner C. 1998. On the origin of incompatible element enrichment in the Venda Nova pluton, Espírito Santo. J. South Am. Earth Sci.,11:473-486.

Machado R. \& Demange M. 1994. Classificação estrutural e tectônica dos granitóides neo-proterozóicos do Cinturão Paraiba do Sul no
Estado do Rio de Janeiro. Bol. IG-USP, Série Cient., 25:81-96.

Matos G., Ferrari P., Cavalcanti J. 1980. Projeto Faixa Calcária CordeiroCantagalo. DNPM-CPRM, BH, 620 pp.

Medeiros S.R., Wiedemann-Leonardos C., Mendes J.C. 2000. Postcollisional multistage magmatism in the Ribeira Mobile Belt: geochemical and isotopic study of the Varzea Alegre Intrusive Complex, Espírito Santo. Brazil. Rev. Bras. Geoc.. 30(1):30-34

Mendes J.C., Mcreath I., Wiedemann C.M., Figueiredo M.C.H. 1997. Charnoquitóides do maciço de Várzea Alegre: um novo exemplo do magmatismo Ca-alcalino de alto $\mathrm{K}$ no arco magmático do Espírito Santo. Rev. Bras. Geoc., 27(1):13-24

Mendes J.C., Junho, M.C., Ghizi, A. 2002. Geology and geochemistry of granitic and dioritic rocks of the São José do Ribeirão intrusive massif, mountain region of Rio de Janeiro State, Brazil. Rev. Un. Rural, série Ci. Exatas e da Terra, 21(2):1-11.

Mercy E.L.P. 1965. Caledonian igneous activity. In: G.Y. Craig (editor), The geology of Scotland. Oliver \& Boyd, Edinburgh, pp 229-267.

Snoke A.W., Quick J.E., Bowman H.R. 1981. Bear Mountain igneous complex, Klamath Mountains, California: an ultrabasic to silicic calc-alkaline suite. J. Petrology, 22:501-552.

Sun S.-S. \& Mcdonough W.F. 1989. Chemical and isotopic systematic of oceanic basalts: implications for mantle composition and processes. In: Magmatism in the Ocean Basins. Geol. Soc. Sp. Pub., 42:313 345 .

Trouw R.A., Heilbron M.P., Ribeiro A., Paciullo F.P., Valeriano C., Almeida J.C., Tupinambá M., Andreis R.R. 2000. The central segment of the Ribeira Belt. In: U. Cordani, E. Milani, A. Thomaz Filho, D. Campos. (eds.) Tectonic Evolution of South America. CPRM-SBG, Rio de Janeiro, 856 pp.

Tupinambá M. 1999. Evolução tectônica e magmática da Faixa Ribeira na região serrana do Estado do Rio de Janeiro. Tese de Doutoramento. IG-USP, São Paulo. 222p.s

Manuscrito A-1398 Recebido em 23 de dezembro de 2002 Revisão dos autores em 20 de novembro de 2003 Revisão aceita em 26 de novembro de 2003 